FILOLOGIJA 73, Zagreb 2019.

UDK 81'282.2(497.561)

DOI https://dx.doi.org/10.21857/yq32oh42p9

Izvorni znanstveni članak

Rukopis primljen 23. IX. 2019.

Prihvaćen za tisak 28. X. 2019.

Marina Marinković

Zavod za lingvistička istraživanja

Hrvatska akademija znanosti i umjetnosti

Ulica književnika Ante Kovačića 5, HR-10000 Zagreb

mvalencic@hazu.hr

\title{
DISLOCIRANI GOVORI GORSKOGA KOTARA: MJESNI GOVORI VUKMANIĆA I KNEZ GORICE
}

U radu se na temelju vlastitoga terenskoga istraživanja prikazuje fonološka (i dijelom morfološka) analiza mjesnih govora Vukmanića i Knez Gorice. Sela Vukmanić i Knez Gorica smještena su 14 kilometara jugoistočno od Karlovca, a prema navodima iz povijesnih izvora njihovo je stanovništvo na prostor sjevernoga Korduna doseljeno početkom 18. stoljeća iz gorskokotarskih predjela. Dosadašnji istraživači spomenute su idiome dijelili različito: prve je podatke o njima dao Stjepko Težak (1957) istaknuvši da se na čakavsko-kajkavsko-štokavskome terenu karlovačkoga kraja radi o punktovima s najviše čakavskih osobina. Čakavskome ikavsko-ekavskome dijalektu pripojila ih je i Iva Lukežić (1990), a na Karti kajkavskoga narječja Mije Lončarića (1996) osjenčani su bojama kajkavskoga goranskoga dijalekta. S obzirom na navedena divergentna određenja, a radi njihove što preciznije klasifikacije, istraženi su vokalizam, konsonantizam i prozodija mjesnih govora Vukmanića i Knez Gorice, dok se na planu morfologije donose ona obilježja koja su specifična i koja determiniraju goransko podrijetlo navedenih govora s jedne strane, te arealna obilježja s druge strane, zajednička svim tipovima govora na karlovačkome dijalektološki heterogenome prostoru. Istraživanje je pokazalo da su goranski doseljenici u Vukmaniću i Knez Gorici do danas zadržali brojna obilježja govorâ Gorskoga kotara, a gorskokotarska čakavsko-kajkavska interferencija ogleda se i u analiziranim mjesnim govorima, što potvrđuju neka obilježja: $o$-odraz stražnjeg nazala, sporadična zamjena ${ }^{*} l>0$, zamjena $-m>-n$ u gramatičkim morfemima promjenjivih riječi te leksičkim morfemima nepromjenjivih riječi i dr. Kao i u drugim govorima karlovačkoga kraja, zabilježen je ikavsko-ekavski refleks jata kao supstratni element, osnovno obilježje svih govora karlovačkoga četveroriječja, no ovo je istraživanje potvrdilo i da na sinkronijskoj razini ekavizmi daleko više nadmašuju ikaviz- 
Marina Marinković: Dislocirani govori Gorskoga kotara: mjesni govori Vukmanića...

FILOLOGIJA 73(2019), 79-101

me, kao i da je prijeporno govoriti o ovim govorima kao govorima sa zamjenom jata prema pravilu Meyera i Jakubinskog.

\section{Uvod - dosadašnja istraživanja, obrazloženje teme, metodologija}

O govorima dvaju sela smještenih na krajnjem sjeveru Korduna, ${ }^{1} 14$ km jugoistočno od Karlovca, Vukmanića i Knez Gorice, kroz dosadašnji je dijalektološki rad hrvatska filologija dobila tek osnovne spoznaje, $\mathrm{u}$ formi nuzgrednih zapažanja stečenih prilikom ekspedicija koje bi redovito obuhvaćale veoma velik i dijalektološki veoma heterogen prostor. Polovicom prošloga stoljeća nakon takovoga tipa istraživanja prve je podatke o njima dao Stjepko Težak (1957) i vraćao im se na temelju tih rezultata i u mlađim radovima $(1979 ; 1997)$. Ishodi njegova dijalektološkoga angažmana na karlovačkome terenu poslužili su za daljnje zaključke i u novijim monografijama sintetskoga tipa (Lukežić 1990; Lončarić 1996). Premda se na prvi pogled doima da radova o navedenim govorima ne manjka (posebice u usporedbi s nekim obližnjima, potpuno neistraženim govorima) i da je govoriti dalje o njima zalihosno, problem nastaje već u trenutku kad se pokušaju klasificirati u hijerarhijski više sustave i postaviti u širi dijalektološki kontekst. Naime, u spomenutoj Težakovoj raspravi iz 1957. autor ističe da se radi o punktovima s najviše čakavskih osobina i da »svojim govorom strše kao neki otok između štokavskih sela Korduna i karlovačkoga kajkavsko-ikavskog područja « (1957:419). Međutim, 20-ak godina kasnije, u radu koji se bavi čakavsko-kajkavskom interferencijom u govorima lociranima sjeverno i sjeverozapadno od Karlovca, uočljivo je Težakovo izuzimanje govora Vivodine iz analize za koji je utvrđeno da se "poput govora u Vukmaniću i Knez Gorici može uvrstiti u kajkavsko narječje goranskoga tipa « (1979:39-40). Na tragu ovih podataka, na preciznijim dijalektološkim kartama područje oko Vukmanića osjenčano je bojama kajkavskoga goranskoga dijalekta.

1 Vukmanić i Knez Gorica smješteni su na samome razmeđu Pokuplja i Korduna. Kao geografska regija, Kordun je "najlabavije" omeđen upravo na svojim sjeveroistočnim granicama, »između Petrove gore i karlovačkog Pokuplja, gdje na području suvremene općine Gvozd (ranije Vrginmost), a manjim dijelom i općine Vojnić, dolazi do preklapanja povijesnih regija Banije/Banovine i Korduna« (Pejnović 2009:15). Kako najveći dio opće literature ova sela smješta na Kordun (Karlovački leksikon 2008:315; 627), a i tamošnji stanovnici smatraju se više žiteljima Korduna negoli Pokuplja, u ovome radu priklonili smo se takvome geografskome određenju. 


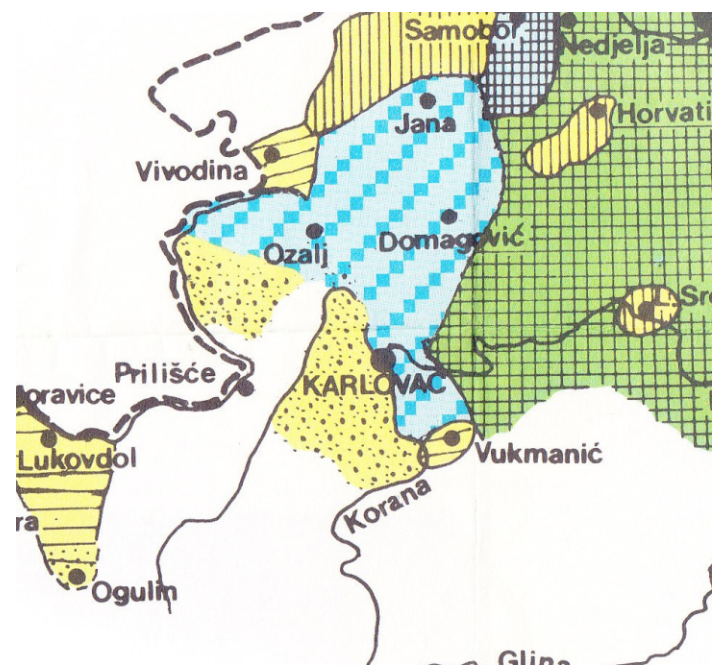

Karta 1. Isječak iz Karte kajkavskog narječja, Lončarić 1996.

Drugi je primjer oprečnih teza o ovim mjesnim govorima vezan uz pitanje odraza jata. Odredivši upravo mjesne govore Vukmanića i Knez Gorice kao »naročit primjer miješanja slovensko-kajkavsko-čakavsko-štokavskog«, na ikavsko-ekavskome potezu od Ogulina do, ugrubo, Žumberka, Težak ih izuzima iz daljnje obrade budući da "govor tih sela nije ikavsko-ekavski« (Težak 1997:205). No, punktovi Vukmanić i Knez Gorica uvršteni su na koncu u zonu ikavsko-ekavske zamjene jata pokupskoga područja, u okviru poznate čakavološke monografije (Lukežić 1990:24).

Kako bismo razjasnili nejasnoće te utvrdili uzroke današnje dijalektološke situacije u ovim dvama mjesnim govorima, valjalo je poduzeti terensko dijalektološko istraživanje ${ }^{2}$ te posegnuti za povijesnim vrelima. Na temelju dosadašnjih naznaka o fizionomiji ovih dvaju govora, šireg dijalektološkog konteksta u koji su uronjeni ${ }^{3}$ te nakon inicijalnih spoznaja o goranskome podrijetlu žitelja Vukmanića i Knez Gorice ${ }^{4}$ iskristaliziralo se

2 Terensko dijalektološko istraživanje provedeno je u više navrata tijekom 2016. te potom jednokratno u proljeće 2019. godine.

3 S međunarječnim i međudijalekatskim prožimanjima na širem karlovačkom prostoru hrvatska je dijalektologija upoznata još od početka prošloga stoljeća (Strohal 1901; Rešetar 1907), istraživanja su se intenzivirala 70-ih godina te potom u novije vrijeme (pregled dijalektoloških istraživanja karlovačkoga Pokuplja dân je u Marinković 2014 ). Dok su se stariji istraživači pretežito bavili globalnim problemom tronarječnosti, pokušavajući povući izoglose, recentniji radovi upustili su se u analizu na mikrorazini: istražujući preciznije fonologiju pojedinih mjesnih govora. Sva su istraživanja potvrdila da je uglavnom riječ o miješanim i prijelaznim govorima te da je u većini mjesnih govora riječ o supostojanju jezičnih crta raznorodna podrijetla.

4 Usp. sljedeće poglavlje. 
nekoliko zadataka ovoga rada s ciljem preciznijega pozicioniranja mjesnih govora Vukmanića i Knez Gorice na dijalektološkoj karti hrvatskoga jezika:

- $\quad$ istražiti fonologiju mjesnih govora Vukmanića i Knez Gorice ${ }^{5}$

- usporediti najvažnije vokalske (odrazi jata, poluglasa, stražnjega nazala), akcenatske i specifične konsonantske (zamjena $-m>-n$ ) osobine navedenih govora s fonološkim osobinama goranskih govora te obližnjih govora karlovačkog Pokuplja

- istražiti neke morfološke osobine (imenska deklinacija, konjugacija) i usporediti ih s morfološkim osobinama goranskih govora te obližnjih govora karlovačkog Pokuplja

- utvrditi starije i inovativnije slojeve u današnjim govorima Vukmanića i Knez Gorice

- na koncu, dopuniti prijašnje fragmentarne podatke na objema razinama (fonološkoj i morfološkoj) te navedene mjesne govore pokušati smjestiti u hijerarhijski više sustave.

Istraživanje je, zbog navedenih ciljeva i zadataka, provedeno prema utvrđenim načelima dijalektologije kao sastavnice genetske lingvistike. $U$ potrazi za ispitanicima nastojali smo stoga pronaći govornike koji što više čuvaju starije stanje. U Vukmaniću su tako ispitane i snimljene izvorne govornice Evica Malčić (r. 1927.), Mare Manjarić (1932. - 2019.), Milka Muić (r. 1949.) i Irena Prpić (r. 1968.), a u Knez Gorici Katica Crnković (r. 1945.) i Ana Muić (r. 1941.). Ovim putem zahvaljujem svim ispitanicama na trudu i susretljivosti.

\subsection{Društveno-povijesni okvir}

Susjedna naselja Vukmanić i Knez Gorica administrativno pripadaju području grada Karlovca. Poznato i kao rodno mjesto Ivana Ribara te preporoditelja Ivana Derkosa, prema popisu stanovništva iz 2011. selo Vukmanić broji 207 stanovnika, a Knez Gorica čak upola manje, svega 111. Do 1991. Knez Gorica zvala se Knežgorica (Karlovački leksikon 2008:315). S južne su i istočne strane oba sela okružena štokavskim govorima Kordu-

5 U analizi govorâ dalje Vu (Vukmanić) i KG (Knez Gorica). Budući da se potvrde dobivene ciljanim ispitivanjem (odrazi polaznih vokala, konsonanata i prozodema) iz obaju punktova podudaraju gotovo stopostotno, radi sprječavanja redundantnosti ovdje ih nismo posebno razdvajali, već ih donosimo kumulativno. Razlike između punktova posebno su istaknute i tiču se većinom realizacije pojedinih (ne)vokalskih i prozodijskih segmenata te leksika. Osim toga, druga su obilježja (primjeri vokala, status i distribucija fonema i sl.) ekcerptirana, između ostalog, iz ogledâ govora pa su ona i zapisana odvojeno. 
na i Banovine, Vojnićem, Gornjom Trebinjom, Sjeničakom, Živković Kosom (Petrović 1978:7-20). Osim štokavskoga Tušilovića, prema zapadu ih u međuriječju Korane i Mrežnice omeđuju govori Ladvenjka, Barilovića i okolnih zaselaka, odnosno govori »kajkavsko-ikavskoga narječja, koje je nastalo na čakavskoj bazi« (Težak 1959:456). Sa sjeverne strane graniče također s govorima različitih osnovica: sa štokavskim Popović Brdom i miješanim, kajkavsko-čakavskim govorima karlovačkoga Pokuplja.

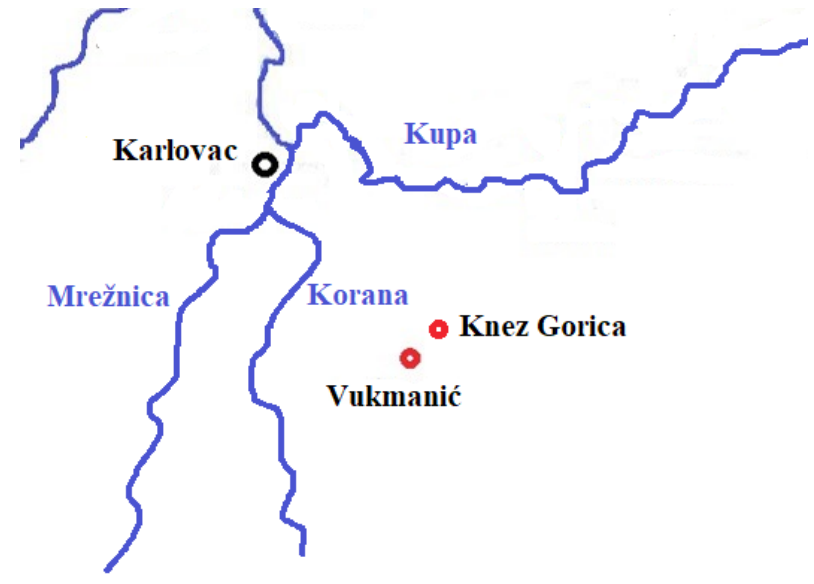

Karta 2. Smještaj Vukmanića i Knez Gorice

Glavno vrelo povijesnih podataka o ovim naseljima Lopašićevo je djelo Oko Kupe i Korane. Kao i ostali brojni lokaliteti u široj karlovačkoj okolici, i Vukmanić i Knez Gorica bili su dijelom vlastelinstva Steničnjak. Prema Lopašićevim spoznajama selo je dobilo ime prema "praotcu plemena Vukmana koji je oko g. 1300. živio i po njegovim unucima Vukmanićima« (1895/1988:285). Široj je javnosti možda nepoznata činjenica da se u povijesnim ispravama ovo selo nazivalo i Fuk. U popisu župa zagrebačke biskupije 1334. i 1501. godine (Buturac 1984) u tadašnjem Fuku djelovala je Župa sv. Trojice. Danas je Vukmanić sjedište Župe svetog Antuna Padovanskog. U povijesnim ispravama Vukmanić se nerijetko spominje i u kontekstu Vukmanićke kumpanije kao sastavnice Slunjske pukovnije Vojne krajine, kojoj je pripadala i, prema zapisu iz 19. stoljeća, Knežgorica (Fras 1988:235-236; Marinović 2003:59-61).

Specifičnost današnje govorne situacije Vukmanića i susjedne Knez Gorice ima povijesne korijene: oko 1700 . g. ova su sela, nakon osmanskih pustošenja, naseljena komorskim kmetovima (tzv. Kranjcima) iz Gorskoga kotara: »...otrgnuv priedjele oko Vukmanića i obližnje Knez-Gorice grofici Mandaleni Nadaždi, vlastelinki u Steničnjaku i Rečici, naseliše (g. 1700. 
gjeneral grof Karlo Auersperg a g. 1705. princip Hanibal Porzia) na pusta zemljišta tako zvane Kranjce, $\mathrm{u}$ istinu pak Hrvate iz obsega današje riečke županije (imena Abramović, Colnar, Kvaternik) « (Lopašić 1895/1988:141). Lopašić precizira dalje da je novo stanovništvo doseljeno iz Moravica, ${ }^{6}$ Broda i Delnica (1895/1988:290).

Antroponomastička građa pruža dodatne argumente tezi o zajedničkoj povijesti Vukmanaca i Goričaka s jedne te Gorana s druge strane. Kao najčešća, u Vukmaniću bilježimo prezimena Muić, Lisac i Manjarić, dok su u Knez Gorici to prezimena Vukelić, Crnković, Obranović, i također Muić.7 Prilagođena fonološkome sustavu lokalnih govora, ${ }^{8}$ prezimena Vukmanića i Knez Gorice ekvivalentna su tako učestalim goranskim prezimenima (Burić 1979).

Gorani su se u poslijeosmanskome periodu selili i u druge krajeve: goranske je govore u Moslavini istraživao Mijo Lončarić (1997), žitelji naselja Španovica u Slavoniji podrijetlom su iz Ravne Gore (Erjavec 2014), a jezični je identitet goranskih kajkavaca u SAD-u, čiji život u američkoj sredini opisuje Rudolf Filipović (1998:177-185), još uvijek nejasan.

\section{Fonološka obilježja}

\subsection{Prozodija}

\subsubsection{Inventar, realizacija i distribucija}

Prozodijski sustav obaju govora čine dva naglaska, dugi i kratki ('V̄, 'V), odnosno razlikovnu funkciju imaju kvantiteta i mjesto naglaska, a opreka po tonalitetu je utrnuta. Utrnute su i nenaglašene dužine. Oba se naglaska izgovaraju silazno, dok je uzlazna realizacija nešto češća ispred sloga s reduciranim vokalom ([víknit t], [nósitt], usp. poglavlje 2.2.1.).

Naglašeni mogu biti svi vokali te slogotvorno r:

Vu: k'apula 'luk', šājtruga 'kariola', dr'ẹpaļka 'alatka za drepanje grož-

6 Nekoć jedinstveno selo koje se dijelilo na dva dijela, starije Gornje Moravice i mlađe Donje, nakon osmanskih haranja i administrativno se rascijepilo na dva mjesta: Gornje Moravice pripale su brodskome vlastelinstvu (vlastelinstvo Broda na Kupi) i prozvane Brod Moravice. Donje Moravice pripale su bečkoj Komori i stoga prozvane Komorske Moravice (Marković 2003:88). Ime Komorske Moravice za to je mjesto bilo u uporabi do 1919. godine, zatim do 1991. Srpske Moravice.

7 O prezimenskome fondu Vukmanića i Knez Gorice usp. i Marinović 2003:22.

8 Usp. primjerice adaptaciju goranskoga prezimena Muhvić u vukmanićko i knezgoričko Muić, uslijed gubitka fonema $x$ iz konsonantskih sustava navedenih mjesnih govora. Prezime Obranović poteklo je vjerojatno od doseljenih Abramovića čiji su nositelji i danas u najvećoj mjeri smješteni u okolici Brod Moravica i Ravne Gore (Burić 1979:53-54). 
Marina Marinković: Dislocirani govori Gorskoga kotara: mjesni govori Vukmanića...

FILOLOGIJA 73(2019), 79-101

đa', r'eklac 'kaput', klas'înac 'oklasak', 'iža, p'ộčac '1. mali put; 2. razdjeljak na glavi', st'ožina 'stog', j'üžina 'ručak', g'udḷa 'smjesa za krvavice',

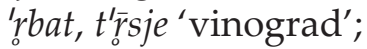

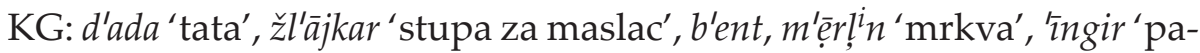
stuh', ž'ito 'proso', 'oroz 'pijetao', r'ọbac, ž'upa 'juha', s'ūša, 'rร̌̆avo, s'šrp.

Kratki naglasak može stajati na inicijalnome i medijalnome slogu te $\mathrm{u}$ jednosložnim riječima, KG: m'ačkare, f'ara, nos'ilo pr. r., zb'or 'proštenje'; Vu: 3̌'iklali pr. r. 'skakali', t'arabe 'ograda', k'ostan, nev'ista, t'uj 'tu', l'ej imp. 'gledaj'.

Dugi naglasak također može stajati na inicijalnome i medijalnome slo$\mathrm{gu}$, na finalnome te $\mathrm{u}$ jednosložnim riječima, KG: r'ọna 'cikla', m'àjka 'baka', r'ūčak 'doručak', čer'ẹšńa, met'ālo pr. r. s., nov'āc G mn., ž'ện G mn., Kamešččāk

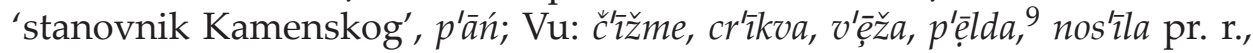
Vukm'ānac, Goričāâk, kok'ọš G mn., g'šrm 'manja šuma', k乞乞 'kao'.

Prema navedenome dade se zaključiti da je naglašena zatvorena ultima potvrđena najvećma u genitivu množine, te u etnicima. Međutim, glavni dio primjera ovjerava kratki naglasak na sekundarno naglašenoj penulti-

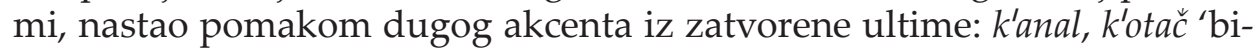
cikl', t'ańir, r'učnik, k'olač, f'azan, kr'umpir, m'ijur 'mjehur', r'ukav.

U medijalnome slogu zabilježena je dvostruka situacija. Samo u manjem broju primjera ovjerava se staro naglasno mjesto, dok je, s druge strane, potvrđen niz primjera regresivnoga pomicanja kratkoga akcenta s medijalnoga sloga: nev'ista, blaz'ina, dvor'ǐšce, strn'išče, posl'ali pr. r.; na p'otoki L

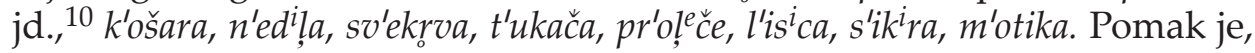
kako pokazuju prethodni primjeri, $u$ velikome dijelu potvrda prethodio redukciji vokala (usp. poglavlje 2.2.1.).

Progresivni pomak dugoga naglaska nije potvrđen: 'oko, d'eset, k'oren, 'oblak, p'epel.

\subsubsection{Podrijetlo}

Kratki je naglasak u mjesnim govorima Vukmanića i Knez Gorice, osim na etimološkim pozicijama (sl'ama, sl'iva, 'oko), potvrđen i na mjestu neocirkumfleksa: ${ }^{11}$ sv'adba, z'ipka, p'auk, k'ikḷa, voz'ilo pr. r., m’amo I jd., pr.

9 U uskliku čuđenja je p’ẹlde! Vukmanić: Je p'ệlde, l'ej k'aj je načıinila!

10 Ovdje smo krenuli s pretpostavkom da se u medijalnoj poziciji neocirkumfleks nije ni razvio. U lokativu jednine nije potvrđen niti u drugim primjerima: v'etri, pr'agi. Kratki se naglasak u L jd. može tumačiti i izostankom dugog nastavačnog ${ }^{*}-\bar{u}$.

11 Kako je analiza ovih govora krenula od pretpostavke da se radi o doseljeničkim govorima s goranskoga kajkavskoga terena, polazni je sustav pri obradi njihove prozodije bio akcenatski sustav D (FO:226), baziran na OKA-i. 
trp. obd'elan, pos'ijan, ist'učen; 1 . jd. prez. br'išen, pl'ujen. U dijelu primjera kratki se naglasak nalazi na sekundarnom mjestu, nakon regresivnoga pomaka neocirkumfleksa na prethodnu kračinu ( $g^{\prime}$ ovedina, 'otava, p'odignol, p'oginol, 'opanki, š'enični, l'opato I jd.), kao u obližnjem mjesnome govoru Brežana (Marinković 2015:86) te u drugim revolucionarnim kajkavskim govorima s metataksom tipa pösekel - posëkli. Kratki naglasak nastaje i pomakom siline s otvorene i zatvorene ultime na prednaglasnu kračinu: n'oga, m'agla, p'osal, b'uva, k'olac, v'oda.

Dugi naglasak $\mathrm{u}$ obama govorima ima raznorodno podrijetlo. U pri-

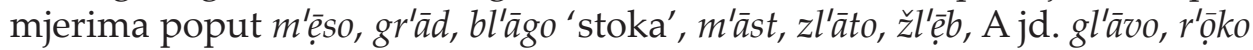
stoji na mjestu staroga cirkumfleksa. Potom se u dijelu primjera javlja na mjestu neocirkumfleksa: $k^{\prime} 0 \underline{a} a$, j'āstreb, k'ọra, r'ūška, r'ộdbina, kukur'ūzni,

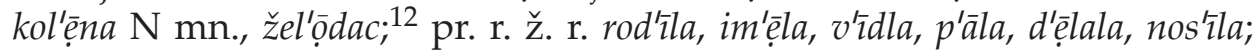
pr. r. m. r. ob'ẹsil, pos'ệkol, im'ệli; m'äčka, pov'ệsmo, čüjen, k'ūvan, pl'äčen se,

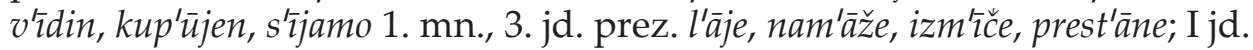
s m'āno, st'ābo, sa s'ābo, b'ābo, kr'āvo, pr. trp. nam'āzan, sr'ẹzan. Dugi se naglasak u primarno naglašenoj ishodišno dugoj penultimi nalazi i na mjestu neoakuta: j'ẹtra, N mn. j'ājca, 'ọkna, reš'ẹta; z'ệle, p'ệrje, s'ệdmi, 'ọsmi, pust'îla pr. r. ž., m'r̂̀la, ml'âtiš. Dugi naglasak nastaje i pomakom siline s ultime (otvorene i zatvorene) i penultime na prednaglasnu dužinu: $k r^{\prime}{ }^{\top} l o,{ }^{13} p^{\prime} e ̣ t a k, r^{\prime} \bar{a} n i l i$ pr. r., gr'āna, f'üčkali pr. r.

Neocirkumfleks se, kako je vidljivo iz prethodnih primjera, ne javlja u svim kategorijama, što je općenito značajkom mnogih kajkavskih govora.

U obama govorima zabilježen je znatan broj primjera s naknadno produljenim vokalima. Sekundarno naglašen i naknadno produljen ishodišno kratak slog potvrđen je u primjerima žẹena, s'ẹstra, s'ệlo, j'ẹzik, j'ệelo, p'ệkli pr. r., gl'ệdat. Na mjestu staroga akuta izvan ultime u nizu primjera potvrđen je također dug naglasak: bl'àto, m'āša, g'ộra 'šuma', j'ệdrika 'jezgra orašastih plodova', na p'āšo A jd., na ń气̂vo A jd., kon'ộpḷa, kr'āvama I mn.,

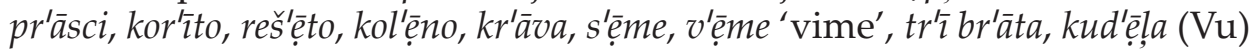
I I kod'ệla (KG). Oba su tipa duljenja sasvim uobičajena u gorskokotarskim kajkavskim govorima (Lisac 1999:149; 2000:32; 2006:89; Malnar 2012:125).

12 Uz osnovno značenje i tradicionalno jelo koje se priprema za Uskrs, vrlo slično goranskome nadjevu.

13 Uz osnovno značenje i dio narodne nošnje. 
Marina Marinković: Dislocirani govori Gorskoga kotara: mjesni govori Vukmanića...

FILOLOGIJA 73(2019), 79-101

\subsection{Vokalizam}

\subsubsection{Inventar, realizacija i distribucija}

Vokalski je inventar monoftonški. U obama govorima u dugome slogu čine ga 6, a u kratkome 5 jedinica:

\begin{tabular}{|c|c|}
\multicolumn{2}{c|}{ Dugi slog } \\
\hline $\bar{l}$ & $\bar{u}$ \\
\hline $\bar{e}$ & $\bar{\rho}$ \\
\hline $\bar{\rho}$ & $\bar{a}$ \\
\hline
\end{tabular}

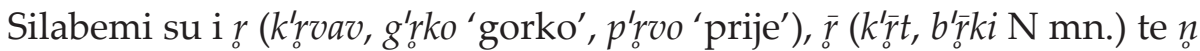
(v'usnca, lub'enca). Potonji je silabem rezultat potpune redukcije vokala $i$.

Fonemi /ẹ/ / /ọ/ izgovaraju se vrlo zatvoreno. Opservirana je i zatvorenija realizacija kratkoga $o$, naglašenog i nenaglašenog: [mọtiko] I jd., [crikvọ] A jd. Zatvaranje kratkoga o posebno je naglašeno u ograničenom broju primjera kada dolazi na mjestu poluglasa. Ponekad se u tim slučajevima u izgovoru zatvara i do fonema $/ u /:$ [jâ sọn $\|$ sun], [jèsun].

Vokal ẹ $\left(<{ }^{*} e\right)$ nerijetko se diftongira: oko mệisa G jd. (Vu), prẹ̣ija (KG).

$\mathrm{U}$ zanaglasnome slogu fonem /i/ često se ostvaruje kao $y$ : [dìcy] D jd., [kròvy] L jd., [ǐzy] L jd. Svi vokali, osim ẹ i ọ, mogu stajati u inicijalnom, medijalnom i finalnom slogu (usp. u poglavlju 2.3.1. odlomak o protetskim konsonantima).

Redukcija zanaglasnog $i$ (u medijalnome slogu te zatvorenoj ultimi) jedno je od značajnijih obilježja vokalskih sustava mjesnih govora Vu i KG: $v^{\prime} a j^{i} k, G^{\prime} o r^{i} c a, s^{\prime} e n^{i} c a, K^{\prime} a t^{i} c a, M^{\prime} a r^{i} c a, c^{\prime} o v^{i} k$, div'ān ${ }^{i} l a$, pros $^{\prime} n^{i} c a$, nač้'in $i l e$ pr. r., $v^{\prime} e^{i} k a, g^{\prime} o d^{i} n a, g^{\prime} o n^{i} t, k^{\prime} o s^{i} l o, p o s ̌ k r^{\prime} o p^{i} t, p^{\prime} z^{\prime} a b^{i} t$. Navedeni primjeri oslikavaju djelomičnu redukciju vokala, u promatranim govorima najčešću, no s nedosljednom provedbom od ispitanika do ispitanika. Primjeri č́etri, k'olko i t'olko ovjeravaju potpunu redukciju. Može se pretpostaviti da su na ovu fonološku promjenu utjecali susjedni štokavski govori karlovačkoga Pokuplja (Marinković 2017:241). U daleko manjem broju primjera potvrđena je

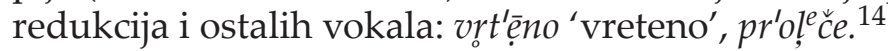

U inicijalnome slogu vokali o/̣̣ zatvaraju se $(o / \bar{p}>u / \bar{u})$ uz nazale u leksikaliziranim primjerima 'unda, 'uni, 'unaj, 'ùn. ${ }^{15}$

14 Budući da su govornici u razgovoru izgovarali i nereducirano pr'oḷeče (a i leksem ljeto potvrđen je s ekavskim odrazom, vidi u nastavku), kod ove smo potvrde krenuli od pretpostavke da je reduciran vokal $e$.

15 Ali: k'olko i t'olko (usp. küḷiko i tüḷiko u obližnjem govoru Brežana, Marinković 2015:88). 
Marina Marinković: Dislocirani govori Gorskoga kotara: mjesni govori Vukmanića...

FILOLOGIJA 73(2019), 79-101

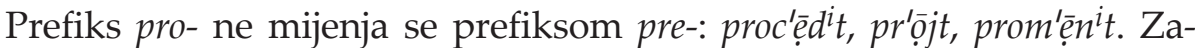
mjena pro- > pre- obilježjem je brojnih kajkavskih govora (Maresić 2017), pa tako i onih lociranih u neposrednome okružju mjesnih govora Knez Gorice i Vukmanića (usp. Marinković 2015:88), te zapadnih kajkavskih govora Gorskoga kotara (usp. u Delnicama primjere prešéplet 'probušiti', prešiéret 'proširiti', prešiétat 'prošetati' i dr., Pavešić-Magaš-Laloš 2006:303). Izostanak ove zamjene u KG i Vu tumačimo ovdje novijim štokavskim utjecajem.

\subsubsection{Podrijetlo}

\subsubsection{Refleks jata}

U mjesnim je govorima Vukmanića i Knez Gorice refleks jata ekavski, te manjim dijelom ikavski. Ekavizmi su u obama govorima potvrđe-

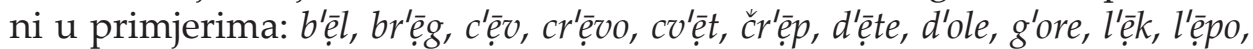
l'ẹšniki, l'eto, m'edved, m'esto, m'ẹsit t'ẹsto, m'era, ml'ệko, mr'eža, oreń'ača, p'ẹsak,

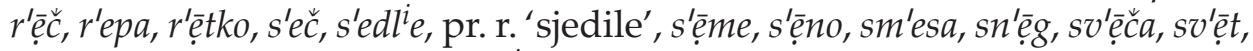
t'ệlo, t'ẹsno, v'ệtar, vr'ẹme, zv'ệzdica.

Ikavski je refleks potvrđen u primjerima vr'iča, d'ica, 'ọrij, m'ijur, m'isec, $s^{\prime} i^{i}{ }^{i} r a, d^{\prime} i v e r, d v \imath$, dv'isto, ist'irala pr. r. Kod relacijskih morfema imeničke deklinacije nema valjana argumenta kojim bismo utvrdili da je nastavak - $i \mathrm{u}$ DLjd. imenica $e$-vrste te u Ljd. imenica $a$-vrste (KG, Vu: d'ici, b'ānki, rộki; na st'oli, $u$ s'ẹli) odraz jata, a ne ishodišnih morfema ${ }^{*}-i /{ }^{*} i, 16$ pa tako ni ove potvrde ne smatramo ikavizmima. Ikavizmi su registrirani u infinitivnoj osnovi glagola I. razreda 3. vrste: $z^{\prime} \imath^{i} t, g^{\prime} \overline{o ̣}^{i} t, s m^{\prime} r d i t$. U dijelu primjera potvrđen je odraz je: bj'ežat, pj'eške, vjenčāńne, s'āvjest, pj'evalo pr. r., smj'ẹšan, p’osḷe.

Iako su ovi mjesni govori pripojeni velikoj skupini hrvatskih govora s ikavsko-ekavskom zamjenom jata prema pravilu Meyera i Jakubinskog (Lukežić 1990), doneseni primjeri ukazuju na dvije važne činjenice: a) dobar dio potvrda odstupa od utvrđene 'formule'; b) omjer ekavizama i ikavizama nije ni približno jednak, odnosno dominiraju ekavizmi, čak i kad se uzmu u obzir likovi u kojima je ikavski refleks naknadno reduciran (tip $\left.c^{\prime \prime} o v^{i} k\right)$. Usporedivši ovu sliku s dijakronijom monoftonških vokalizama Gorskoga kotara, ${ }^{17}$ dade se zaključiti da su govornici mjesnih govora $\mathrm{Vu}$ i KG, kao potomci Gorana iz okolice Delnica i Broda na Kupi, do danas u dobroj mjeri zadržali odraze jata iz prvotne postojbine. Uz one koje možemo priključiti skupini stalnih ikavizama i koji su sasvim uobičajeni diljem

16 Budući da je i u genitivu jednine imenica e-vrste potvrđen odraz palatalne inačice glavne promjene, sasvim je vjerojatno da su i ova dva nastavka u DL jd. kontinuante polazišnih morfema ${ }^{*}-i$.

17 Istočno od mjesta Gornji Turni pa sve do rubnih dijelova istočnogoranskoga kajkavskoga prostora najčešći refleks jata je vokal $e$-tipa, u dugim slogovima redovito zatvoreno $\bar{e}$, a u kratkima vokal $e$ uglavnom srednje otvorenosti. 
Marina Marinković: Dislocirani govori Gorskoga kotara: mjesni govori Vukmanića...

FILOLOGIJA 73(2019), 79-101

kajkavskoga terena (t'irat, s'iki $r a$, usp. Zečević 1993:15), ikavizme tumačimo ovdje novijom, arealnom značajkom, budući da je dvojni odraz jata, s različitim odnosom ikavizama, ekavizama i jekavizama, značajkom većine govora šire karlovačke okolice, neovisno o dijalektološkoj pripadnosti.

\subsubsection{Refleks stražnjeg nazala i slogotvornog!}

Refleks stražnjega nazala i slogotvornog ! također nije jednoznačan. Analiza građe pokazala je da je stražnji nazal uglavnom dao vokal o-tipa,

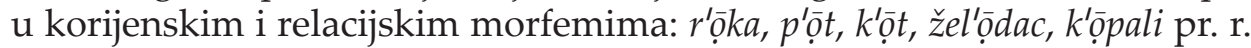
m. 'kupali', okr'ọglo, 3. mn. prez. k'oḷejo, op'erejo, ob'ājdejo, okr'ẹčajo, 'idejo, so (3. mn. prez. gl. biti); A jd. žệno, c'urico, šk'ọlo, šk'ul̦ico. Manji dio primjera ima $u$-odraz: $m^{\prime} \bar{u} z$, g'uska, $z^{\prime} \bar{u} b, b^{\prime} u d e n 1$. jd. prez. Takva je situacija zabilježena i na cijelome kajkavskome prostoru Gorskoga kotara. Slogotvorno je ${ }^{*} l_{o} /{ }^{*} \bar{l}$ dalo vokal $u / \bar{u}: v^{\prime} \bar{u} k, v^{\prime} u n a, \check{z}^{\prime} \bar{u} t, b^{\prime} u v a, s^{\prime} u z a, p^{\prime} \bar{u} z ̌, k k^{\prime} k, j^{\prime} a b u k a$. Veza s goranskom maticom vidljiva je u reliktu s'ọnce ${ }^{18}$ koji u Vukmaniću i Knez Gorici $u$ toj inačici rabe još samo stariji govornici. Naime, zamjena polaznoga slogotvornoga ! vokalom o-tipa, uz ostale kontinuante, također je sasvim uobičajena u zapadnogoranskoj kajkavštini (Lisac 1999:145; 2000:30; 2006:50-51).

\subsubsection{Refleks poluglasa}

U glavnini primjera na mjestu poluglasa u dugom i kratkom slogu dolaze vokali a/ā: k'ādi 'gdje', n'ačka, m'alen 'mlin', z'alva, b'atvo, d'ān, p'ān, t'āst, p'as, d'anas, d'aska, 'osan 'osam', l'akat, s m'āno I jd 'sa mnom'. Vjerojatno analogijom prema I jd. zamjenice j'à u I jd. zamjenicâ $t^{\prime} \imath$ i s'ebe potvrđeni su likovi t'ābo i s'äbo.

Drugi je odraz, fonem /o/, uz izdvojene lekseme s polaznim poluglasom u dočetnome slogu osnove ( $k^{\prime}$ ọtol 'kotao'), potvrđen u kratkom nenaglašenom slogu, $u$ jednini muškoga roda pridjeva radnog te $u$ izdvojenom primjeru (ne)naglašenoga prezenta glagola biti u prvome licu jednine: 'išol, r'ệkol, p'ệkol, t'ệkol, n'āšol, (j'ā) son, j'eson. Uz to, valja napomenuti da je, osim razvoja $-\partial l>-o l$, u obama govorima potvrđen vokal $o$ kao rezultat promjene slijeda -il > -ol: v'idol, sr'ušol, č̌sstol, l'upol 'udario', p'ustol. U zapadnogoranskim govorima potvrđen je u glagolskome pridjevu radnom m. r. jd. razvoj -il > $u(l)$, usp. Malnar 2012:69. Uzmemo li u obzir da na prostoru zapadne Hrvatske, neovisno o dijalektalnoj pripadnosti, slijed ${ }^{*} ə>0$

18 Uz naveden primjer koji će odlaskom starijih govornika vjerojatno nestati iz mjesnih govora $\mathrm{Vu}$ i KG, nekadašnjemu odrazu slogotvornoga $l$ u vokal $o$-tipa svjedočit će još samo povijesna vrela. Da se ovoj zamjeni ne bi potpuno zametnuo trag, korisno je spomenuti i da se u starim ispravama rod Vukmanića (usp. poglavlje 1.1.) zapravo naziva Vokmancima (Lopašić 1895/1988:16). 
nije nepoznanicom, ${ }^{19}$ no na širem karlovačkom terenu dosadašnjim istraživanjima nije potvrđen, ovi nam se primjeri nameću kao još jedna potvrda genetske spone između analiziranih govora i govora zapadnoga rukavca goranske kajkavštine. Isto tako, u sastavu staroga prefiksa *vo- poluglas je dao različite vokale, $a \mathrm{u}$ imenici $V^{\prime} a z a m(\mathrm{KG})$ | | V'azan (Vu) 'Uskrs' te $e \mathrm{u}$ prilogu v'eni (KG). Kod glagola z'ẹt 'uzeti' i njegovih oblika (z'emi 2. jd. imp.)* $v$ - je ispao, a kod primjera udov'̂̀ca, 'unuk, ut'ọrak izjednačen je s odrazom * ${ }^{*}$ - ('umrla II $m^{\prime}$ r̆la).

\subsubsection{Refleksi ostalih polaznih vokala}

Polazni vokali ${ }^{*} a{ }^{*} \bar{a}$ u mjesnim govorima KG i Vu odrazili su se kao $a$ i $\bar{a}: m^{\prime} a k, d l^{\prime} a n, b r^{\prime} a t$, tr'ầva, ml'ätin 1. jd. prez., kr'āv G mn.

Polazni kratki vokali ${ }^{*} e \mathrm{i}{ }^{*} e$ odrazili su se kao srednje $e$, a dugi vokali ${ }^{*} \overline{\mathrm{i}}$ *ē izjednačili su se u fonemu ệ: žep, sv'e, pr'eža (Vu) I| pr'ệja (KG), z'et; m'ẹd, žệnska, j'ẹtra, m'ệso. Osim toga, u građi obaju govora zabilježen je na mjestu etimološkoga $e$ vokal $i$ u primjeru m'ačija 'maćeha' te u GDL jd. pridjevsko-zamjeničke sklonidbe, KG: k'uštraviga || k'uštraviga ps'a, z'eleniga, dr'ūgiga; Vu: G jd. v'elikiga p'oḷa, b'ệliga, l'ẹpiga, crn'乞̨ga, m'ojiga; m'ojin d'ečki D jd. (KG, $\mathrm{Vu}$ ), na p'rôin L jd., u m'ojin s'ẹli L jd. (KG, Vu). No, u obama govorima potvrđen je u G jd. lik t'ega. Vokal $i$ na mjestu iskonskoga $e$ značajkom je goranskih govora zapadnoga tipa (Barac-Grum 1993:186; Lisac 2006:100), ali i govora na širem sjeverozapadnočakavskome teritoriju. Upravo zbog njegove pojavnosti u govorima različitih dijalekata, pa i narječjā, potvrde s razvojem ${ }^{*} e>i$ nazvane su u literaturi hiper- ili pseudoikavizmima, uz naglasak na obveznom razlikovanju od ikavizama čije je podrijetlo isključivo od jata (Vranić 1999:51).

U sekundarno naglašenim slogovima s naknadnim duljenjem polazni kratki fonemi *ę/*e dali su otvoreno ẹ: $j$ 'ệzik, p'ệkli, v'ẹja 'grana'. Zbog kvantitete i naglasnih pomaka polazni se fonem tako rascijepio na dvije jedinice.

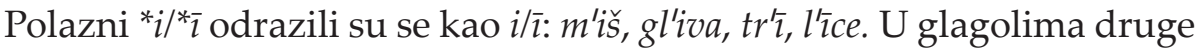
vrste odraz $i$ iz polaznoga morfema *-ny- reduciran je, kao i u ostalim zanaglasnim pozicijama: $d^{\prime}$ ign ${ }^{i} t$, spr'ign $^{i} t, m^{\prime} a k n^{i} t$. Iznimno je u primjeru v'ẹme $\left(<{ }^{*}\right.$ vymę) potvrđen drugačiji odraz, uz naknadno duljenje polaznoga vokala.

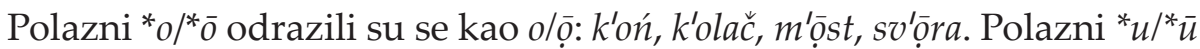
odrazili su se kao $u / \bar{u}: l^{\prime} u k, k r^{\prime} u v, s^{\prime} \bar{u} s ̌ a, p^{\prime} \bar{u} v a t$. Time su se, u okolnostima

19 U mjesnome govoru Dobrinja na otoku Krku ova je zamjena opisana kao »nosilac velike razlikovnosti« (Lukežić-Turk 1998:36). Potvrđena je zatim u dijelu primjera u mjesnome govoru Gornjih Turni (Lisac 2006:41), a u riječi st'oza u nizu goranskih mjesnih govora. 
bez distribucijskih ograničenja (proteza ispred inicijalnih $u / \bar{u}$ ), u glavnini primjera izjednačili odrazi polaznih vokala ${ }^{*} Q /{ }^{*} \bar{Q} \mathrm{i}{ }^{*} O /{ }^{*} \overline{0}$. Izuzev petrificiranoga relikta s'ộnce, s odrazima polaznih ${ }^{*} u /{ }^{*} \bar{u}$ izjednačeni su i odrazi ${ }^{*} l_{0}^{*} \bar{l}$.

\subsection{Konsonantizam}

\subsubsection{Inventar, realizacija i distribucija}

Konsonantski sustav mjesnih govora Vukmanića i Knez Gorice ima 22 fonema:

\begin{tabular}{ccccccc}
\multicolumn{2}{c}{ sonanti } & \multicolumn{5}{c}{ konsonanti } \\
& & $m$ & $p$ & $b$ & $f$ & \\
$j$ & $r$ & $n$ & $t$ & $d$ & & \\
$j$ & $l$ & $n$ & $c$ & & $s$ & $z$ \\
& & $c$ & $\breve{z}$ & $\check{s}$ & $\check{z}$ \\
& & $k$ & $g$ & &
\end{tabular}

Afrikate $c i$ 光 izgovaraju se vrlo umekšano, blisko štokavskim ć i đ. ${ }^{20}$

Finalni se zvučni konsonanti realiziraju i obezvučeno: $p^{\prime} \hat{o} r e z$, $p^{\prime} o d$ 'tavan', n'ọ̄žn, gr'ob.

Fonem $x$ nije dijelom konsonantskih sustava ovih dvaju govora. U inicijalnome položaju ispada, $u$ medijalnome se mijenja fonemima $j \mathrm{i} v$, dok su $\mathrm{u}$ finalnome slogu potvrđeni i ispadanje i zamjena, KG: 'uvatit inf., lad'et'na 'hladetina', p'ejar 'vrč', č́lijamo 1. mn. prez., kr'uv, 'ộrij, pl'āvta, j'ūva, v'rńa; Vu: v'ūvo, l'ače, str'ệja, m'ijur 'mjehur', m'uva, sn'aja, gr'ệj 'grijeh', Vl'aji, p'ūvalo pr. r., gr'a. Gubljenje i supstitucija fonema $x$ temeljna je konsonantska značajka i okolnih štokavskih govora (Marinković 2017:238).

Zamjena $-m>-n$ u gramatičkim morfemima promjenjivih riječi te leksičkim morfemima nepromjenjivih riječi bitan je razlikovni element naspram ostalih govora karlovačkoga areala, Vu: z'ôven, prepučājen 'propu-

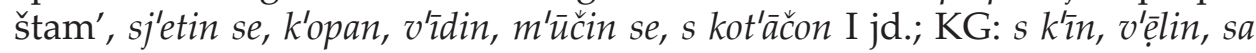

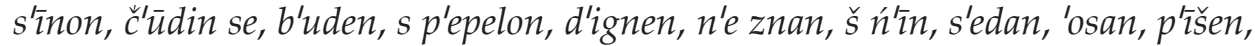
$l^{\prime} o z ̌ i n .{ }^{21} \mathrm{Uz}$ već poznata područja s ovom zamjenom, valja istaknuti da je

20 Prilikom terenskoga istraživanja zabilježena je u samim mjestima istraživanja uzrečica kojom stanovnici okolnih sela opisuju govor žiteljâ Vukmanića i Knez Gorice, a u kojoj je izgovor fonema č dodatno, artificijelno umekšan: Poč́upali se $m^{\prime} a ̈ c k i u$ Gor`̌̌čkin j'ārki. Na tragu toga, i zbirka priča karlovačkog književnika Damira Valenta (također Vukmanca) nosi naslov Poćupali se maćki.

21 Poznatu u dijalektologiji i kao adrijatizam, na ovu je pojavu, zahvaljujući novijim istraživanjima, u recentnoj literaturi bačeno posve novo svjetlo. Analiza provedena na korpusu materijala za Hrvatski jezični atlas (Menac-Mihalić-Celinić 2016) pokazala je da prostiranje ove fonološke neutralizacije nadmašuje nekadašnje poimanje: 
Marina Marinković: Dislocirani govori Gorskoga kotara: mjesni govori Vukmanića...

FILOLOGIJA 73(2019), 79-101

ona sasvim obična i u gorskokotarskim čakavskim (u mjesnome govoru Vrbovskoga, Barac-Grum 1993:144), ikavskim štokavskim (Crnić Novosel 2019:92-94) i brojnim govorima zapadnoga kajkavskoga poddijalekta (Lisac 2006:63-64). Istočnogoranski kajkavski govori tu zamjenu ne provode (Marinković 2018:175).

U prezentskim oblicima glagola moći potvrđen je rotacizam: m'oren 1 . jd. prez., m'ore 3. jd. prez., m'orejo 3. mn. prez. U prezentskoj i imperativnoj osnovi glagola prefigiranih od glagola ići čuva se skup jd: d'ọjden 1. jd. prez., d'ọjdejo 3. mn. prez., z'ājde 3. jd. prez., a u infinitivnoj skup jt: d'ọjt

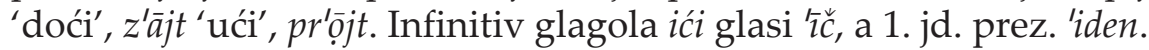

Vokali $u$ i $\bar{u}$ u inicijalnoj poziciji dobivaju (u dijelu primjera) protezu v-: v'ura, v'ūsta, v'ūvo, v'ūńa 'ujna', v'uja 'ujak', v'ugal, v'uzal, v'učtit. Proteza nije potvrđena $u$ medijalnoj intervokalnoj poziciji ( $\left.n^{\prime} a u c^{\prime} i t\right)$ te $u$ primjerima 'učitel i 'ūḷe. Protetsko se j javlja samo u osobnim imenima: J'āndre, J'āne. Protetsko $x$ nije zabilježeno (usp. imenicu $r^{\prime} \bar{a} z ̌$ u obama govorima).

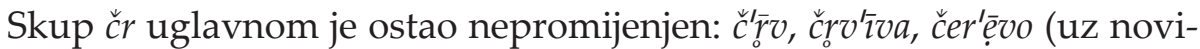

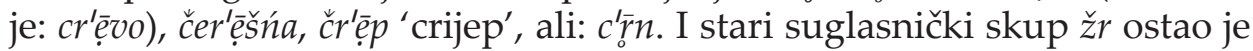
nepromijenjen u oblicima glagola žerat inf., žereš 2. jd. prez.. Konsonant $d$ umetnut je u imenici ždr'ệbe, $\check{z} d r^{\prime} e b^{i} c a$. Zabilježene su i druge suglasničke promjene, odnosno ispadanja u suglasničkim skupinama: pov'ica 'savijača' (<pov'itica), š'en ${ }^{i} c a, t^{\prime} \hat{\imath} c a, l^{\prime} a \bar{s} i$. Promjena $r a>r e$ potvrđena je u obama govorima samo u primjeru vreẹbac 'vrabac'.

\subsubsection{Podrijetlo}

Polazni, opsl. ${ }^{*} t$ (psl. $\left.{ }^{*} t j\right)$ izjednačio se sa starim ${ }^{*} \check{c}$ u afrikati ${ }^{c}:$ četri,

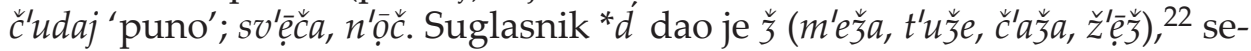

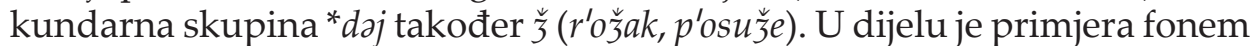

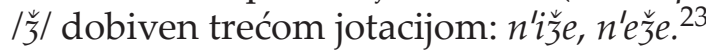

Suglasnički skup st́ $\left(<{ }^{*} s t j={ }^{*} s k j\right)$ dao je suglasničku skupinu šč: dvor'išče,

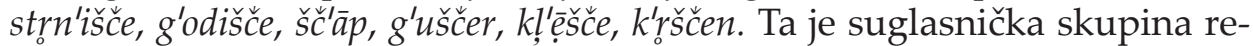
zultat i stapanja suglasnika u sekundarnome skupu stj $\left(<{ }^{*} s t a j\right)-l$ lš̌če,

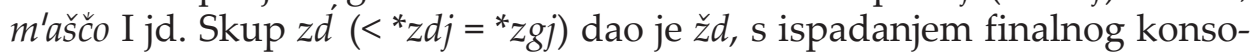

osim u uzobalnom području, zabilježena je tako i u govorima sjeverozapadne Hrvatske, zalazi duboko u prostor Gorskoga kotara, a potvrđena je i u doseljeničkom goranskom govoru Gornje Jelenske u Moslavini. Kako je zamjena - $m>-n$ zabilježena i u mjesnim govorima Vukmanića i Knez Gorice, a buduća istraživanja otkrit će ju vjerojatno i na drugim područjima, opravdano je predložiti raspravu o njenu preimenovanju. Ili, u konačnici, nazivati ju samo delabijalizacijom ili fonemskom zamjenom.

22 Razvoj $^{*} d>j$ potvrđen je samo u primjeru pr'ẹja (KG).

23 Trećom je jotacijom dobiven i fonem /č/ u primjeru č'edan 'tjedan' u obama govorima. 
nanta: $d^{\prime} a z ̌$. Primjer je čuvanja nepromijenjene sekundarne skupine $z d j \mathrm{~s}$ ispadanjem dentala $d$ imenica gr'ộzje u $\mathrm{Vu}$ te s metataksom konsonanata gr'ọjze u KG 'grožđe'.

\section{Iz morfologije}

Premda morfološke činjenice pri dijalektološkim klasifikacijama nemaju težinu odabranih i ustaljenih fonoloških kriterija, u nastavku ćemo dati pregled imeničke deklinacije i nekoliko drugih morfoloških osobitosti koje mjesne govore Vukmanića i Knez Gorice smještaju u kontekst ostalih govora u okružju.

Nastavci su imeničke deklinacije u mjesnim govorima Vukmanića i Knez Gorice sljedeći:

$a$-vrsta, muški rod:

\begin{tabular}{|l|c|c|c|c|c|c|c|}
\hline padež & $\mathrm{N}$ & $\mathrm{G}$ & $\mathrm{D}$ & $\mathrm{A}$ & $\mathrm{V}$ & $\mathrm{L}$ & $\mathrm{I}$ \\
\hline $\mathrm{jd}$. & $-\varnothing /-o$ & $-a$ & $-u,-i$ & $-\varnothing /-a$ & $-\varnothing$ & $-i$ & $-o n$ \\
\hline $\mathrm{mn}$. & $-i$ & $-o v$ & $-i m a$ & $-e$ & $-i$ & $-i,-i m a$ & $-i,-i m a$ \\
\hline
\end{tabular}

$a$-vrsta, srednji rod:

\begin{tabular}{|l|c|c|c|c|c|c|c|}
\hline padež & $\mathrm{N}$ & $\mathrm{G}$ & $\mathrm{D}$ & $\mathrm{A}$ & $\mathrm{V}$ & $\mathrm{L}$ & $\mathrm{I}$ \\
\hline $\mathrm{jd}$. & $-o /-e$ & $-a$ & $-u,-i$ & $-o /-e$ & $-o /-e$ & $-i$ & $-o n$ \\
\hline $\mathrm{mn}$. & $-a$ & $-\varnothing$ & $-i m a$ & $-a$ & $-a$ & $-i,-i m a$ & $-i,-i m a$ \\
\hline
\end{tabular}

e-vrsta:

\begin{tabular}{|l|c|c|c|c|c|c|c|}
\hline padež & $\mathrm{N}$ & $\mathrm{G}$ & $\mathrm{D}$ & $\mathrm{A}$ & $\mathrm{V}$ & $\mathrm{L}$ & $\mathrm{I}$ \\
\hline $\mathrm{jd}$. & $-a$ & $-e$ & $-i$ & $-o$ & $-a$ & $-i$ & $-o$ \\
\hline $\mathrm{mn}$. & $-e$ & $-\varnothing$ & $\begin{array}{c}-a m, \\
-a m a\end{array}$ & $-e$ & $-e$ & $-a,-a m a$ & $-a m a$ \\
\hline
\end{tabular}

$i$-vrsta:

\begin{tabular}{|l|c|c|c|c|c|c|c|}
\hline padež & $\mathrm{N}$ & $\mathrm{G}$ & $\mathrm{D}$ & $\mathrm{A}$ & $\mathrm{V}$ & $\mathrm{L}$ & $\mathrm{I}$ \\
\hline $\mathrm{jd}$. & $-\varnothing$ & $-i$ & $-i$ & $-\varnothing$ & $-i$ & $-i$ & $-i,-j o$ \\
\hline $\mathrm{mn}$. & $-i$ & $-i, \varnothing$ & $\begin{array}{c}-a m i, \\
-i m a\end{array}$ & $-i$ & $-i$ & $-i m a$ & $\begin{array}{c}-i m a \\
-a m a\end{array}$ \\
\hline
\end{tabular}

Razmotrit ćemo ovdje samo neke morfeme, razlikovne prema morfološkim sustavima obližnjih govora (prema Težak 1957; 1959, 1979; FinkaŠojat 1973:117). U mjesnim je govorima Vukmanića i Knez Gorice razvidna različitost u DLjd. imenica $a$-vrste u kojima relacijski morfem lokativa jed- 
nine kontinuira polazni morfem ${ }^{*}-i$, naspram morfema $-u$, posuđenog iz ishodišne $u$-deklinacije i ukorijenjenog u svima dosad istraženim govorima karlovačke okolice. Morfem - $i$ uveden je u dativ vjerojatno analogijom prema lokativu (D jd. vr'āgi, še êfi) i uz -u rabe ga još samo stariji govornici. U mjesnome govoru Knez Gorice zabilježeni su primjeri lokativa jednine $u$ G'ộrsken k'otari, na V'ukmaniči, kan'āli, na krôli, s'ẹli, u L'adveńki (< L'adveńak), po d'āni 'danju', u MUP-i, a u Vukmaniću K'ārlovci, na sv'ẹti, u v'inni, u r'ati, u Skak'āvci, u l'uki, u Z'āgrebi. Ovaj je nastavak potvrđen i u zapadnogoranskim kajkavskim govorima (Lisac 2000:32; 2006:94-99).

Uz manji broj relikata s neproširenom osnovom (KG, Vu: r'ogi ‘dio narodnoga pokrivala', kr'aji, b'⿳⺈⿴囗十 $i)$, jednosložne imenice muškoga roda u množinskim oblicima $u$ analiziranim govorima nerijetko su proširene nerelacijskim morfemom -ov (nepalatalne osnove) ili -ev (palatalne osnove), KG: p'opovi, z'ecovi, vr'agovi, st'olovi, p'üževi; Vu: m'iševi, n'osevi, m'üževi. Uz stare nastavke, u obama govorima potvrđena je (sve češća) uporaba inovativnih nastavaka, odnosno ujednačavanje u DLI mn. svih triju rodova (KG: DLI mn. s'inovima, s'ệlima, m'äčkama, k'ostima; Vu: d'ečkima, p'oḷima, žệnama, k'ostima). Uz utjecaj standarda, razloge ovih ujednačavanja svakako valja potražiti i u susjednim novoštokavskim govorima s jednakim množinskim paradigmama (Marinković 2017:240).

U prezentu drugoga lica množine u uporabi je nastavak -šte, kao i u zapadnim goranskim govorima (Lisac 2000:33; 2006:107-108), KG: m'ộrešte, vel'̌šste, zn'äšte, gl'ẹdašte; Vu: div'ānište, p'̌̀ješte, 'idešte, n'osište. Podrijetlo ovoga nastavka tumačimo ovdje analogijom, odnosno preuzimanjem formanta -š- iz drugoga lica jednine koje se dogodilo svakako u vrijeme dok je $\mathrm{u}$ uporabi bila dvojina (prije njena nestanka polovicom 15. st.), a radi sprječavanja morfološke homonimije između 3. lica dvojine (s nastavcima -ete, -jete, -ate i -ite) i 2. lica množine. Budući da u ostalim kajkavskim (i čakavskim i štokavskim) govorima dosadašnjim istraživanjima nije zabilježen (Lukežić 2015:317), u okviru hrvatskoga jezika ovaj je nastavak zasad specifikum zapadnogoranske kajkavštine.

Kao i na cijelome kajkavskome goranskome prostoru (Lisac 2006:107; Marinković 2018:174), utrnuta je morfološka i funkcionalna opreka između supina i infinitiva, KG: 'iden sp'at / n'e moren sp'at; Vu: 'ajmo sk'äkat 'trčati' / n'e moren sk'äkat.

U okamenjenoj sintagmi $d v^{\prime} \bar{j} j e$, trộje... d'ici (KG, Vu) čuva se relikt staroga oblika nominativa dvojine imenica ženskoga roda.

U obama govorima u uporabi su upitno-odnosne zamjenice $k^{\prime} a j$ i d'o. 


\section{Mjesni govori Vukmanića i Knez Gorice u odnosu na goranske govore i govore karlovačkoga areala - istosti i razlike}

Dok inozemna, uglavnom anglosaksonska literatura dijalektološkome kontaktu pristupa pretežno iz sociolingvističke perspektive, nastojeći pružiti objašnjenja za jezične promjene u urbanim sredinama te postupno nestajanje tradicionalnih ruralnih govora (Trudgill 1986; Britain 2018), i u kroatističkim okvirima u fokusu je takvih recentnih istraživanja dobrim dijelom ispitivanje odnosa i interferencija između organske osnovice i standarda. Takve interferencije rezultiraju neorganskim govornim tipovima koji se svode pod zajednički termin interdijalekta (usp. Brozović 2004:9; Blažeka 2007) i temeljno je njihovo obilježje manji ili veći stupanj promjena (u odnosu na polazišnu organsku osnovicu), uzrokovanih izvanjezičnim razlozima. Kod ovdje analiziranih mjesnih govora, riječ je, međutim, o drugačijem tipu kontaktološkoga fenomena, a koji na hrvatskome teritoriju (zahvaljujući opet nešto starijim izvanjezičnim - povijesnim čimbenicima) nije rijedak. Navest ćemo ovdje samo jedan takav primjer u neposrednome dijalektološkome okruženju: govor Hrvatskoga Sela doseljeni je kajkavski otok smješten južno od Kupe, na Banovini usred kompaktne i prostorno velike štokavske cjeline, u čijim se fonološkim i morfološkim obilježjima ogleda niz štokavskih utjecaja (Zečević 2000:7-120).

U kojim se segmentima današnjih fonoloških (i morfoloških) sustava govora Vukmanića i Knez Gorice, smještenih izvan Gorskoga kotara, preslikava goransko podrijetlo? Valja ponajprije podsjetiti na hrvatskoj dijalektologiji poznat fenomen goranske jezične zbilje koju također obilježava prožimanje različitih osobina, a velik je dio gorskokotarskih govora određen upravo interferencijom kajkavskih i čakavskih osobina (usp. BaracGrum 1993). Izdvojit ćemo ovdje samo neke osobine knezgoričkog i vukmanićkog govora kao poveznice s kajkavsko-čakavskim govorima Gorskoga kotara: dvoakcenatski sustav, duljenje refleksa starog akuta izvan ultime, vokal $o$-tipa na mjestu stražnjega nazala, nekoć i na mjestu samoglasnoga l (rọ̣ka, d'ico A jd., p'ệnzijo A jd., k'oḷejo 3. mn. prez., s'ộnce, itd.), zamjena $-m>-n$ u gramatičkim morfemima promjenjivih riječi te leksičkim morfemima nepromjenjivih riječi (n'厃sson 'nisam', 'osan, 'iman), nastavak -šte u 2. 1. mn. prezenta ( $\left.z n^{\prime} \bar{a}^{2} \mathrm{t} t\right)$, nastavak $-i \mathrm{u}$ DL jd. imenica $a$-vrste, utrnuta opreka infinitiva i supina. Druge ih osobine približavaju pak ostalim govorima karlovačkog areala: glasovi č (fonetski veoma blisko štokavskome c) i $\breve{z}^{3}$ u sustavu, redukcija zanaglasnog $i$, gubljenje glasa $x$, primjeri treće 
jotacije, nerelacijski morfemi -ov/-ev u svim oblicima množine u jednosložnih imenica muškoga roda, sinkretizam nastavaka u DLI mn.

U akcentuaciji današnjih mjesnih govora KG i Vu vide se jasno dva sloja: u prvome, starijemu, naknadno produljeni slogovi (i primarno i sekundarno naglašeni) zrcale naslijeđenu akcenatsku sliku zapadne goranske kajkavštine. Usporedimo li, međutim, distribuciju kratkih i dugih naglasaka govora Vu i KG s distribucijom većine goranskih kajkavskih govora, vidjet ćemo da se ona unekoliko razlikuje, a ponajviše se to dotiče dvaju akcenatskih pomaka: a) pomak siline dugoga naglaska iz zatvorene ultime na prethodnu kračinu (tip k'otač) i b) regresivni pomak siline medijalnoga akcenta koji stoji na mjestu neocirkumfleksa (tip 'otava). Prvi je svojstven goranskim govorima s predznakom kajkavsko-čakavske interferencije (Marinković 2018:78-81), a drugi obližnjim govorima karlovačkoga Pokuplja, na rubovima prostiranja Ivšićeve turopoljsko-posavske cjeline. Potonji je, međutim, proveden nedosljedno (pos'ệkol, kup'üjen : 'otava, $g^{\prime}$ oved $\left.{ }^{i} n a\right)$, što govori da se suvremena akcenatska slika ovih dvaju govora ne može poistovjetiti u potpunosti niti s ishodišnim govorima Gorskoga kotara, niti s govorima u novoj okolini, kao niti s Ivšićevim utvrđenim akcenatskim tipovima i da je na širokom potezu od Ozlja (uključivo s karlovačkim bazenom) pa do zapadnih krajnjih točaka Gorskoga kotara riječ o posve novome tipu govora s "formulom" pos'ẹk $a(o) l$ - pos'ẹkli. Ambivalentna distribucija starog kratkog naglaska (blaz'ina, nev'ista: $\left.t^{\prime} u k a c ̌ a, l^{\prime}{ }^{i}{ }^{i} c a\right) \mathrm{s}$ tendencijom regresivnoga pomaka upućuje također na kolebanje u sustavu koji polako stremi novijemu stanju, odnosno stanju arealne nivelacije s (dijalektološki raznorodnim) govorima u susjedstvu. Dvojake su i mogućnosti naknadnoga duljenja: primjeri poput s'ẹlo i $v^{\prime} o d a$, jasno ukazuju na to da je na djelu tendencija pojednostavnjivanja akcenatskoga sustava, što je u kontekstu dijalekatskoga miješanja posve uobičajena pojava.

U kontekstu arealnih značajki valja pobliže protumačiti i odraz jata u današnjim govorima Knez Gorice i Vukmanića. Suprotno inicijalnim očekivanjima, ovo je istraživanje pokazalo da pravilo Meyera i Jakubinskog nije dokraja primjenjivo na ova dva govora, odnosno da su ikavizmi rezultat novijega kontakta (preuzeti od okolnih govora manje ili više prema Meyer-Jakubinskij obrascu; dio primjera pripada skupini tzv. stalnih ikavizama) i da bi u dijakronijskome smislu valjalo govoriti ponajprije o ekavskim govorima. Ako dalje uzmemo u obzir mlađi jezični sloj, to jest ikavizme prije njihove redukcije $u$ zanaglasnome položaju, onda opcionalno i o ekavsko-ikavskim govorima. 
Marina Marinković: Dislocirani govori Gorskoga kotara: mjesni govori Vukmanića...

FILOLOGIJA 73(2019), 79-101

\section{Zaključak}

Na razini sustava, između analiziranih govora nema značajnijih razlika. Među ispitanicima vlada mišljenje da stanovnici Vukmanića više "otežu", navodeći kao ilustraciju primjere s naknadno produljenim vokalima na primarno i sekundarno naglašenim slogovima. Kako je naknadno duljenje $\mathrm{u}$ istome obimu (pa čak i na istim primjerima) potvrđeno i u Knez Gorici, radi se naprosto o duljoj realizaciji. Različiti primjeri odraza polaznih jedinica ( $r^{\prime} e^{3} \breve{a} a(\mathrm{Vu})$ : prệja $(\mathrm{KG})$ ) javljaju se u opsegu koji odista ne utječe na konačne zaključke i klasifikaciju.

Na početku rada zadano je nekoliko zadataka ovoga istraživanja. Izvršivši prethodne, došli smo do zadnjega, no i najkompleksnijega zadatka: uvrstiti mjesne govore Vukmanića i Knez Gorice u hijerarhijski više sustave. Na području Gorskoga kotara opisano je dosad niz govora prijelaznoga karaktera čija je fizionomija uvjetovana višestoljetnim kontaktom govorâ različitih narječja. Zoran je primjer takvoga govora mjesni govor Osojnika unutar istočnogoranskoga kajkavskoga poddijalekta s akcenatskom shemom potpuno srodnom akcenatskoj slici obližnjih čakavskih govora ogulinsko-modruške provenijencije. Budući da su predci stanovnika koji danas nastanjuju sela Vukmanić i Knez Goricu početkom 18. stoljeća izmješteni iz svoga okružja i naseljeni na novi teren, tako i o tima dvama mjesnim idiomima trebamo govoriti i u kontekstu štokavskoga superstrata koji je na prostoru sjevernoga Korduna u ovome slučaju odigrao veliku ulogu.

Uzevši u obzir sve (p)opisane karakteristike, kao nužno nameće se dalje pitanje treba li navedene govore zvati miješanima, nastalima kao rezultat kretanja stanovništva, poput drugih govora šire karlovačke okolice ${ }^{24}$ Da bismo izbjegli kakofoniju terminâ i dodatna pojašnjavanja, ovdje analizirane mjesne govore priključujemo goranskome kajkavskome dijalektu, dopuštajući odstupanja od zamišljene "idealne" goranske jezične slike, kao što tome dijalektu pripada i niz drugih govora kojima je dijalektološka slika "narušena" brojnim inodijalekatskim utjecajima, poput već spomenutog mjesnog govora Osojnika ili Mrkoplja koji čakavskim elementima remeti homogenost gorskokotarske ikavske štokavštine. ${ }^{25}$ Stoga bi u narednim sintetskim opisima uz kajkavski goranski dijalekt valjalo vezi-

24 Ovisno o stupnju prevlasti bilo kajkavskih, bilo čakavskih osobina u kojem analiziranom govoru, oni su u dosadašnjim istraživanjima nazivani različito: kajkavsko-čakavski, čakavsko-kajkavski, kajkavci ikavci i sl., pod krovnim terminom međunarječja (usp. Težak 1979).

25 Usp. Lukežić 2008; Marinković 2018; Crnić Novosel 2019. 
vati i mjesne govore Vukmanića i Knez Gorice, kao što su u sklopu dosadašnjih opisā dijalekata i narječja ostali dislocirani govori u zemlji i inozemstvu pridruživani svojim maticama.

\section{Literatura}

Barac-Grum, Vida. 1993. Čakavsko-kajkavski govorni kontakt u Gorskom kotaru. Rijeka: Izdavački centar Rijeka.

Blažeka, Đuro. 2007. Međimurski interdijalekt. Rasprave Instituta za hrvatski jezik i jezikoslovlje, 33, 1-18.

Britain, David. 2018. Dialect Contact and New Dialect Formation. Ur. Boberg, Charles i dr. The Handbook of Dialectology. Wiley-Blackwell, 143158.

Brozović, Dalibor. 2004. O dijalektologiji kao jezikoslovnoj disciplini. Suvremena lingvistika, 57-58, 1-12.

Burić, Antun. 1979. Povijesna antroponimija Gorskog kotara u Hrvatskoj. Goranska prezimena kroz povijest. Rijeka: Društvo za zaštitu prirodne, kulturne i povijesne baštine Gorskog kotara.

Buturac, Josip. 1984. Popis župa zagrebačke biskupije 1334. i 1501. godine. Starine, 59, 43-108.

Crnić Novosel, Mirjana. 2019. Štokavski ikavski govori u Gorskome kotaru. Zagreb: Institut za hrvatski jezik i jezikoslovlje.

Erjavec, Zvonimir. 2014. Ravnogorski rječnik. Rječnik ravnogorsko-sušičkošpanovačkoga dijalekta. Ravna Gora: Udruga »Plodovi gorja Gorskog kotara «.

Filipović, Rudolf. 1998. Hrvatski identitet iseljenih Gorana u SAD-u. Ur. Sakić, Vlado i dr. Budućnost iseljene Hrvatske. Zagreb: Institut društvenih znanosti »Ivo Pilar«, 175-185.

Finka, Božidar; Antun Šojat. 1973. Karlovački govor. Hrvatski dijalektološki zbornik, 3, 77-151.

$\mathrm{FO}=$ Fonološki opisi srpskohrvatskih/hrvatskosrpskih, slovenačkih i makedonskih govora obuhvaćenih Opšteslovenskim lingvističkim atlasom. 1981. Ur. Ivić, Pavle i dr. Sarajevo: ANUBiH.

Fras, Franjo Julije. 1835./1988. Cjelovita topografija Karlovačke vojne krajine (pretisak). Prir. Benvin, Anton. Gospić: Ličke župe.

Ivić, Pavle. 1961. Prilozi poznavanju dijalekatske slike zapadne Hrvatske. Godišnjak Filozofskog fakulteta u Novom Sadu, 6, 191-212.

Kapović, Mate. 2015. Povijest hrvatske akcentuacije. Fonetika. Zagreb: Matica hrvatska.

Karlovački leksikon. 2008. Ur. Ott, Ivan i dr. Zagreb: Školska knjiga. 
Marina Marinković: Dislocirani govori Gorskoga kotara: mjesni govori Vukmanića...

FILOLOGIJA 73(2019), 79-101

Lisac, Josip. 1999. Ravnogorska kajkavština i goranski dijalekt. Hrvatski govori, filolozi, pisci. Zagreb: Matica hrvatska, 139-165.

Lisac, Josip. 2000. Osnovne značajke brodskoga govora. Kaj, 33, 5, 25-36.

Lisac, Josip. 2006. Tragom zavičaja. Split: Književni krug.

Lončarić, Mijo. 1990. Jezični odnosi u karlovačkom Pokuplju i Beloj krajini. Ur. Križan, Ljiljana. Kaj - jučer i danas. Čakovec: Zrinski, 132-147.

Lončarić, Mijo. 1996. Kajkavsko narječje. Zagreb: Školska knjiga.

Lončarić, Mijo. 1997. Goranski govor u Moslavini (Gornja Jelenska, Moslavačka Slatina). Suvremena lingvistika, 43-44, 131-139.

Lopašić, Radoslav. 1895./1988. Oko Kupe i Korane (pretisak). Karlovac: Gradska knjižnica »Ivan Goran Kovačić«.

Lukežić, Iva. 1990. Čakavski ikavsko-ekavski dijalekt. Rijeka: Izdavački centar Rijeka.

Lukežić, Iva. 2008. Mrkopaljski govor. Hroatski dijalektološki zbornik, 14, 293-324.

Lukežić, Iva. 2015. Zajednička povijest hrvatskih narječja. 2. Morfologija. Zagreb - Rijeka - Čavle: Hrvatska sveučilišna naklada - Filozofski fakutet u Rijeci - Katedra Čakavskog sabora Grobnišćine.

Lukežić, Iva; Marija Turk. 1998. Govori otoka Krka. Crikvenica: Libellus.

Malnar, Marija. 2012. Fonološki opis čabarskih govora na frazeološkom korpusu. Doktorski rad. Zagreb: Filozofski fakultet.

Maresić, Jela. 2017. Prefiksi pre-, pro-, pri- i pra- u kajkavskome narječju. Hrvatski dijalektološki zbornik, 21, 217-228.

Marinković, Marina. 2014. Dosadašnja dijalektološka istraživanja istočnoga karlovačkoga Pokuplja. Svjetlo: časopis za kulturu, umjetnost i društvena zbivanja, 3-4, 34-43.

Marinković, Marina. 2015. Iz fonologije mjesnoga govora Brežana kraj Karlovca. Hrvatski dijalektološki zbornik, 19, 79-97.

Marinković, Marina. 2017. Ikavsko-ekavski refleks jata u štokavskim govorima istočnoga karlovačkoga Pokuplja. Hrvatski dijalektološki zbornik, 21, 229-248.

Marinković, Marina. 2018. Kajkavski govori istočnoga Gorskoga kotara. Zagreb - Delnice: Hrvatska sveučilišna naklada - Ogranak Matice hrvatske Delnice.

Marinović, Marinko. 2003. Povjesnica Župe svetoga Antuna Padovanskog u Vukmaniću. Vukmanić: Rimokatolička župa sv. Antuna Padovanskog.

Marković, Mirko. 2003. Gorski kotar: stanovništvo i naselja. Zagreb: Naklada Jesenski i Turk.

Menac-Mihalić, Mira; Anita Celinić. 2016. Završni $m$ i $n$ u hrvatskim govorima. Ur. Botica, Stipe i dr. Zbornik radova šestoga hrvatskoga slavistič- 
koga kongresa. Zagreb: Hrvatsko filološko društvo - Hrvatski slavistički odbor, 323-332.

Pavešić, Marija; Blaženka Magaš; Željko Laloš. 2006. Réjč do ríči: beséjdnek déjuonškega devoána. Rječnik delničkoga govora. Delnice - Rijeka: Adamić.

Pejnović, Dane. 2009. Zapadna Hrvatska. Socijalno-geografska preobrazba u drugoj polovini 20. stoljeća. Zagreb: Prosvjeta.

Petrović, Dragoljub. 1978. Govor Banije i Korduna. Novi Sad - Zagreb: Matica srpska - Prosvjeta.

Rešetar, Milan. 1907. Der štokavische Dialekt. Wien: Kaiserliche Akademie der Wissenschaften.

Strohal, Rudolf. 1901. Jezične osobine u kotaru karlovačkom. Rad JAZU, $146,78-153$.

Šojat, Antun. 1979. Položaj karlovačkih govora među hrvatskim dijalektima. Ur. Zatezalo, Đuro. Karlovac 1579. - 1979. Zbornik radova. Karlovac: Historijski arhiv u Karlovcu, 271-274.

Težak, Stjepko. 1957. O rezultatu dijalektoloških istraživanja u okolici Karlovca. Ljetopis JAZU, 62, 418-423.

Težak, Stjepko. 1959. Izvještaj o istraživanju govora između Korane i Mrežnice. Ljetopis JAZU, 63, 456-458.

Težak, Stjepko. 1979. Sjeverni govori čakavsko-kajkavskog međunarječja u karlovačkom četveroriječju. Radovi Zavoda za slavensku filologiju, 16, 37-53.

Težak, Stjepko. 1997. Međunarječna prožimanja u čakavsko-kajkavskim ikavsko-ekavskim govorima. Hrvatski dijalektološki zbornik, 10, 203-208.

Trudgill, Peter. 1986. Dialects in Contact. Oxford: Basil Blackwell.

Vranić, Silvana. 1999. Neke morfonološke (i morfološke) značajke sjeverozapadnočakavskih rubnih govora. Hrvatski dijalektološki zbornik, 11, 4961.

Zečević, Vesna. 1993. Fonološke neutralizacije u kajkavskom vokalizmu. Zagreb: Zavod za hrvatski jezik.

Zečević, Vesna. 2000. Hrvatski dijalekti u kontaktu. Zagreb: Institut za hrvatski jezik i jezikoslovlje. 


\title{
Dislocated dialects of Gorski Kotar: dialects of Vukmanić and Knez Gorica
}

\begin{abstract}
The paper gives a phonological (and partly morphological) analysis of the dialects of Vukmanić and Knez Gorica on the basis of the author's own field research. The villages of Vukmanić and Knez Gorica are located $14 \mathrm{~km}$ southeast of Karlovac, and according to historical sources, their population moved from the region of Gorski Kotar to the area of northern Kordun in the early 18th century. So far, researchers have categorised these dialects in a different way: the first information about them was given by Stjepko Težak (1957), who pointed out that the checkpoints with the most Chakavian features were on the Chakavian-Kajkavian-Shtokavian terrain of the Karlovac area. Iva Lukežić also categorized them under Chakavian-Ikavian-Ekavian dialect, and on the Kajkavian dialect map by Mijo Lončarić (1996), they were marked with the colors of the Kajkavian Gorski Kotar dialect. Considering these divergent determinations, and in order to classify them as accurately as possible, the vocalism, consonantism, and prosody of the dialects of Vukmanić and Knez Gorica were explored, while the morphology features that were included in the research refer to specific features, as well as those determining the Gorski Kotar origin of the mentioned dialects on the one hand, and areal features on the other hand, common to all types of dialects in the Karlovac dialectologically heterogeneous area.

The research has shown that the settlers of Gorski Kotar in Vukmanić and Knez Gorica have retained many features of Gorski Kotar dialects to this day, and the Gorski Kotar-Chakavian-Kajkavian interference is also reflected in the analyzed dialects, which is confirmed by some features: 0 -reflection of the ${ }^{*} Q$, sporadic replacement $l>0$, the substitution of $-m>-n$ in grammatical morphemes, etc. As in other dialects of the Karlovac region, the Ikavian-Ekavian reflex of jat was confirmed as a substrate element. For all those reasons dialects of Vukmanić and Knez Gorica should be concidered as (dislocated) dialects of Gorski kotar.
\end{abstract}

Ključne riječi: goranski kajkavski dijalekt, dijalektološki kontakt, fonologija, morfologija, Vukmanić, Knez Gorica

Keywords: kajkavian dialect of Gorski kotar, dialect contact, phonology, morphology, Vukmanić, Knez Gorica 
